\title{
Profondeur de champ in Jean Renoir's The Golden Coach
}

By Barry Nevin

Fall 2012 Issue of KINEMA

\section{ARTIFICE IN DEPTH: THE EVOLUTION OF PROFONDEUR DE CHAMP IN JEAN RENOIR'S THE GOLDEN COACH}

The ideal response to the problem posed by colour is to completely avoid [...] the vérité extérieure and work entirely in studio décor. [... ] The vérité intérieure is often hidden behind a purely artificial environment. ${ }^{(1)}$

- Jean Renoir

[...] Realism in art can only be achieved through artifice. ${ }^{(2)}$

- André Bazin

The Golden Coach (1953), filmed in the aftermath of Renoir's American experience and the production of The River, can appear somewhat anomalous within the context of his career: the deep, singular hues of the Indian environment and the British family's residence in The River (1951 [cf. Figs. A - B]) are sacrificed for the multicoloured commedia dell'arte costumes worn by Camilla and the rest of the theatre troupe.

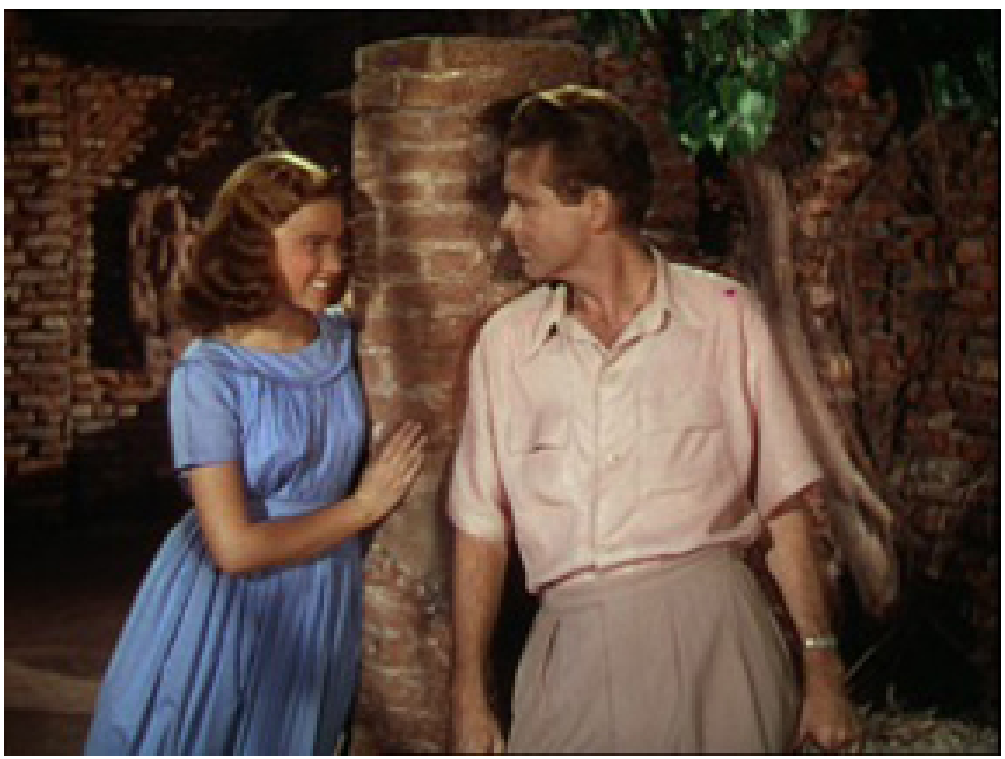

Figure 1: Figures A - B. Two examples of use of Technicolor in The River (1951): the first conveys the simplicity of the colour palette. The second exemplifies the deep, saturated hues favoured by Renoir for this film.

Most surprisingly, the relational complexities created by the intricate organisation of space for which Renoir's work of the 1930s was championed by the critics of Cahiers du Cinéma (most notably André Bazin) ${ }^{(3)}$ and continues to be lauded to this day, are largely renounced.

Strikingly absent in The Golden Coach is Renoir's use of the mobile camera. Nowhere in this vivid reflection on the theatrical are we reminded of the constant swooping of the camera and the lateral depth of field granted by the much-debated $270^{\circ}$ pan during the climatic murder sequence of Le Crime de Monsieur Lange (1935). Even the less attentive viewers among those previously acquainted with Renoir's work will immediately notice the relegation of depth in favour of framing in The Golden Coach (cf. Fig. C).

Renoir had previously exploited deep space to illustrate the unity of men in La Grande Illusion (1937 [cf. Fig. D]), and the obsessive vigilance of both the upper class and servants in La Règle du jeu (1939) as well as the 


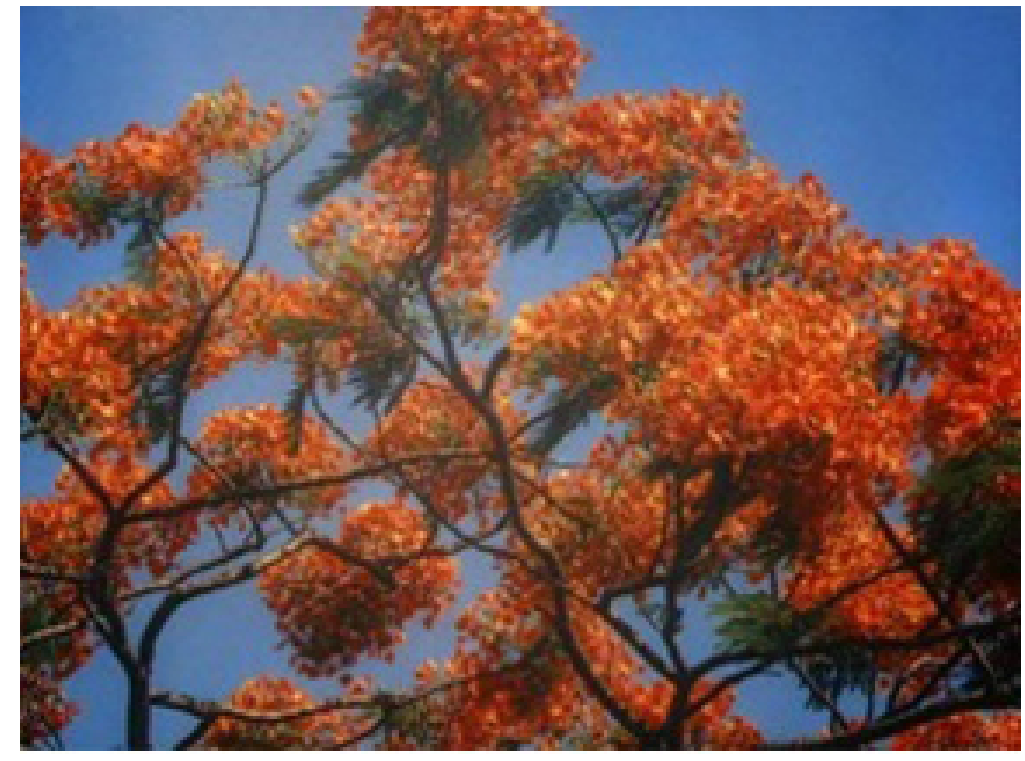

Figure 2: Figure B.

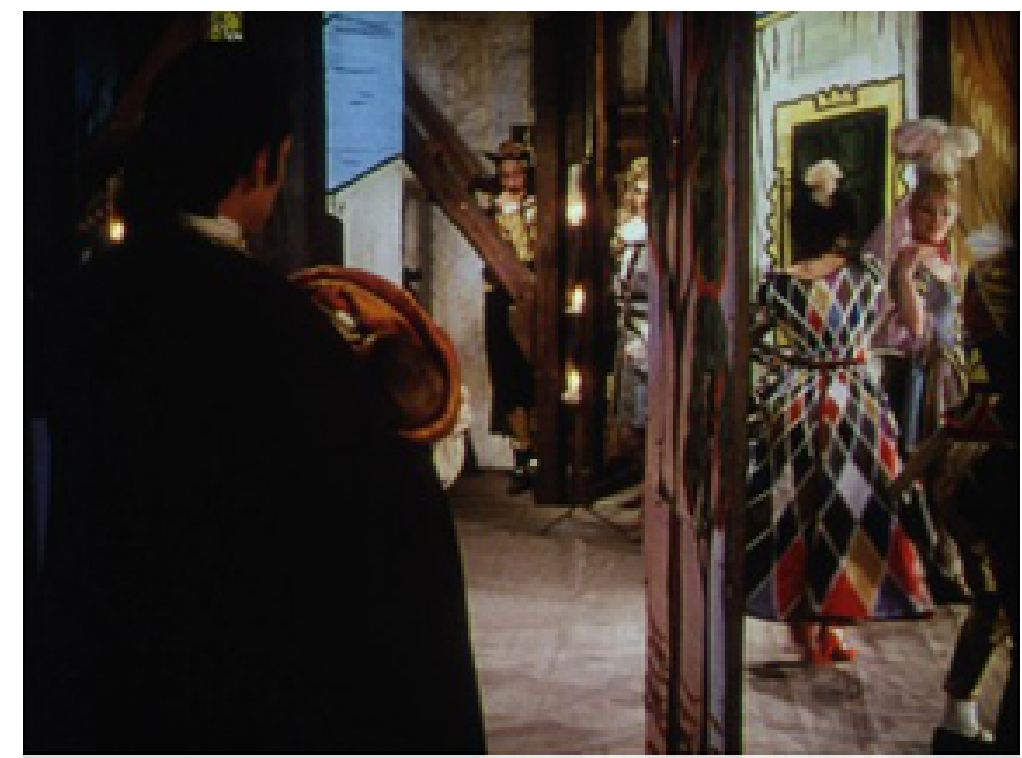

Figure 3: Figure C: Reliance on framing: Renoir largely abandons the lateral depth of field exploited in $L e$ Crime de Monsieur Lange (1935) and La Règle du Jeu (1939), preferring to contain multiple relations and viewpoints within a static frame. Here, Felipe observes Camilla from backstage before departing $\uparrow$ for India. 
interconnectedness of the different rooms within the Château de la Colinière. Even in The River, generally acknowledged as a departure for Renoir, key messages may be derived from the counterpoint produced by the activities that saturate multiple planes of the image. In The Golden Coach however, Renoir daringly departs from his usual repertoire of techniques by largely eschewing the discursive potential offered by deep staging and drifts towards pure theatre. It is no surprise that the director's depiction of the boundaries between life and art might confirm for some what his previous film, The River, had suggested: that Renoir had added Technicolor to his arsenal of techniques at the expense of the mobile camera in a body of work which was becoming increasingly reliant on framing and superficially appealing décor.

Nonetheless, Renoir's reflection on the actor's profession is not completely devoid of the techniques that established him as one of the most innovative directors of the 1930s. One has but to compare the aforementioned examples of composition in depth with three instances featured in The Golden Coach to determine the extent to which the film equally conforms to and deviates from standard staging in depth. In this essay, I aim to discuss the evolution in Renoir's exploitation of deep space in The Golden Coach with reference to the director's use of framing and off-screen space. In light of an analysis of three stylistically different deep shots from the film and André Bazin's theories related to profondeur de champ, I aim to locate the function of composition in depth within Renoir's spectacle-based approach to artifice. The techniques used to convey certain meanings became increasingly refined over the course of Renoir's career, sometimes to such an extent that the message of Renoir's cinematographic language only becomes clear when viewed in relation to the rest of a given film or even his entire oeuvre. Thus my interpretation of Renoir's organisation of space shall also be informed by moments of choice from his other works.

Before delving into The Golden Coach, it is necessary to establish a crucial distinction between two possible translations of profondeur de champ, an expression quite deliberately included in the title of this essay due to its very ambiguities: whilst the term may be translated either as "depth of field" or "staging in depth". Bordwell and Thompson note that:

Depth of field should not be confused with the concept of deep space [...]. Deep space is a term for the way the filmmaker has staged the action on several different planes, regardless of whether all of these planes are in focus. [...] Deep space is a property of mise-en-scène, the techniques that affect what is placed in front of the camera. Depth of field depends on the camera itself, with the lens determining what layers of the mise-en-scène are in focus. [...] In Hollywood during the 1940s, partly due to the influence of Citizen Kane, filmmakers began using faster film, short-focal-length lenses, and more intense lighting to yield a greater depth of field. The contract-signing scene from Citizen Kane offers a famous example. This practice came to be called deep focus. ${ }^{(4)}$

Paulus remarks that despite confusion between these English terms in studies of Renoir's work, Renoir never employed deep focus cinematography in his films of the 1930s. ${ }^{(5)}$ Indeed, the scene in which Legrand shaves in La Chienne and the moment where Christine de la Cheyniest turns to switch off the radio during André Jurieux's outburst in La Règle du jeu each employ shifts in focus which do not feature in the sharp images of the "contract-signing scene" (cf. Figs. E- F).

As we shall see, Renoir persisted in employing the deep staging in The Golden Coach despite its more primitive status within technological discourse. One may argue that the French term is deceptive through the manner in which it implies both modes of exploiting depth. However, it is important to remember that Bazin's theories aim to emphasise the selective nature of the spectator's viewing process as permitted by the photography of multiple planes rather than the technical apparatus employed by the film's creators. As a result, directors who employed different film-making technology (for example, Renoir's use of deep staging in La Règle du jeu and Orson Welles use of deep focus in Citizen Kane) each belong within the singular evolution of profondeur de champ according to Bazin's theory.

The first notable use of deep staging occurs as Camilla and the Viceroy wander through a wooden balcony leading from the ballroom following her troupe's performance at the palace (cf. Fig. G). In one of the Viceroy's most genuine moments of relaxed familiarity, he removes his wig. Through a door leading to the ballroom, the viewer perceives other members of the Viceroy's court dancing beyond a doorway while he and Camilla speak. Profondeur de champ functions here to establish tension between the Viceroy and Camilla's respective relations with each other and their surroundings. This is the world to which the Viceroy belongs 


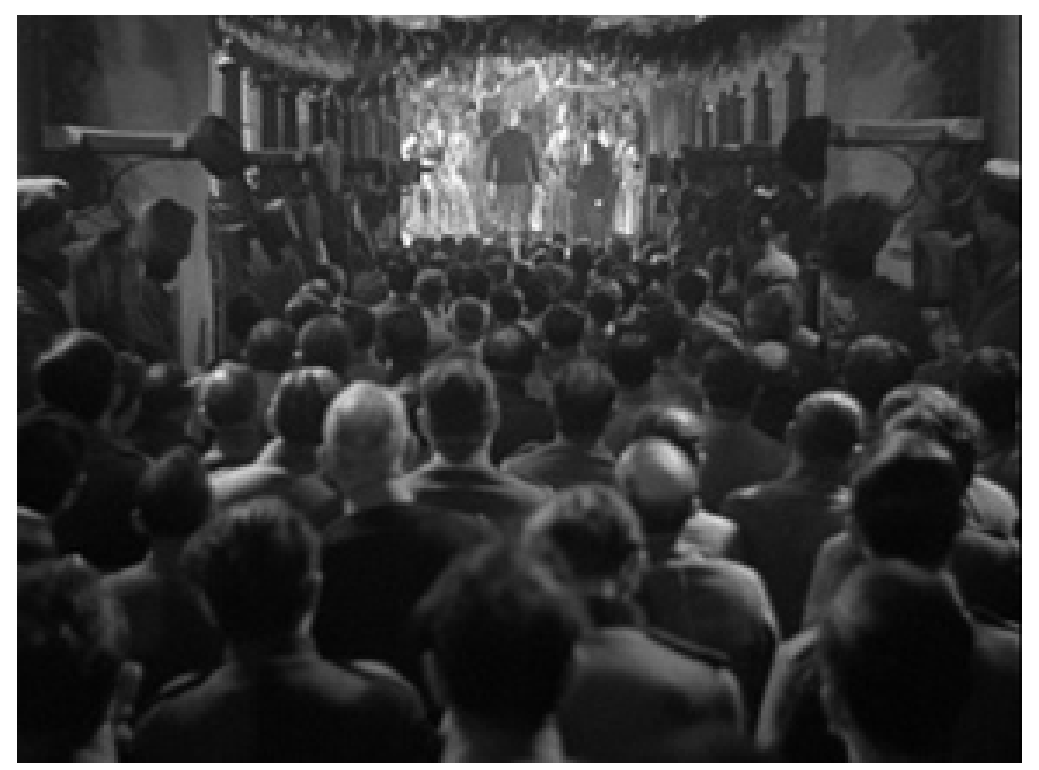

Figure 4: Figure D: An example of composition in depth taken from La Grande Illusion (1937)
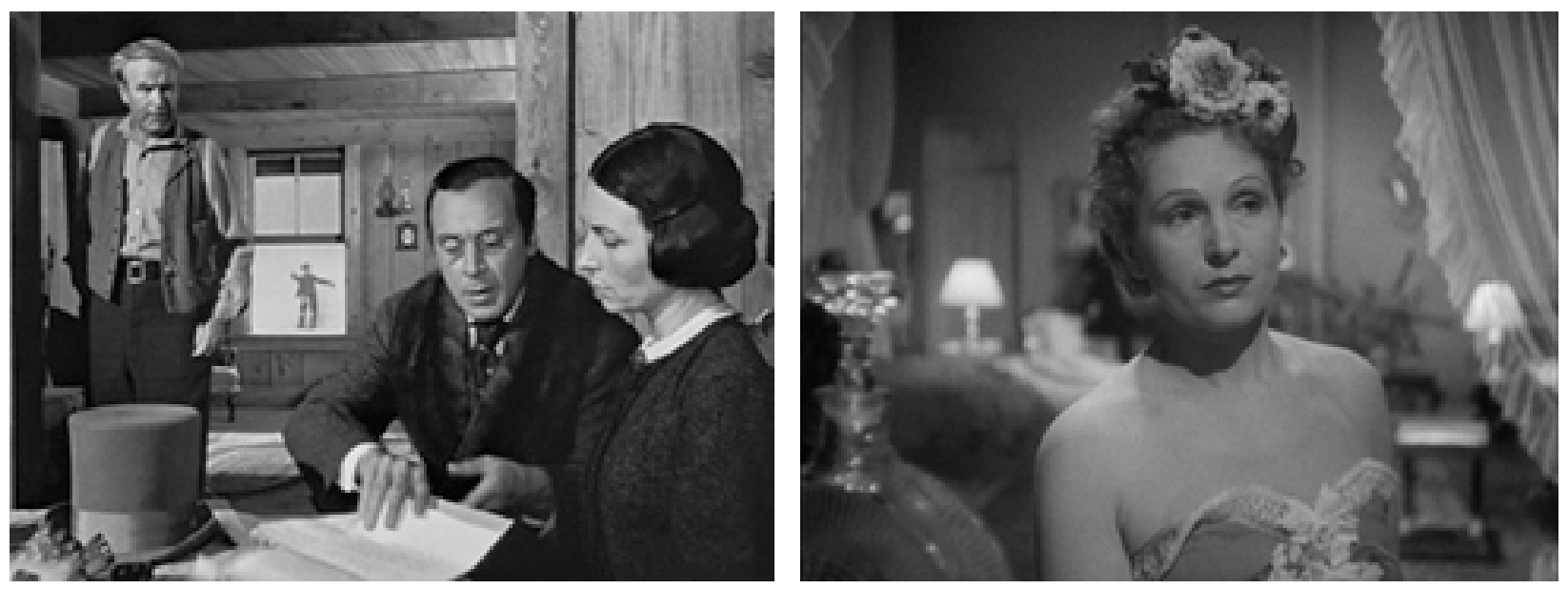

Figure 5: Figures E- F. 
and which Camilla invades: despite the Viceroy's aplomb, the intimacy of the setting and the informality of the meeting itself, Camilla is doomed to remain an outsider. Any sense of ease offered by the Viceroy's demeanour is irreflective of the general attitude of hauteur that pervades the court. A two-dimensional, "flat" approach to the image indicates the weight of the self-absorbed upper class on the Viceroy's spirit: as the Viceroy bends over the wooden balcony and ponders over his status and wealth with Camilla, the distant image of the court dancing in the ballroom appears directly above his hanging head.

The nobility constitutes a veritable ball-and-chain through its omnipresence within the palace and conservative sense of tradition, echoed by their disapproval of the Viceroy's taste in theatre, in taxes and in women. Thus the location of the door through which we see them in the frame undercuts any hopes for an unproblematic union between the two culturally-opposed characters. Whether one subscribes to the latter interpretation or not, one can agree that the depth of the image appropriately emphasises the behavioural gulf between the Viceroy and his court through its contrapuntal composition. The image thus remains undeniably orthodox within the context of Renoir's career and that of cinematographic realism.

Our second example, this time occurring within Camilla's residence, also exploits deep space in a practical, objective manner. By now, Camilla has obtained her coveted coach and awaits the Viceroy, only to become hostess to both Ramon the bullfighter and Felipe (the first of her three loves within the narrative) before the Viceroy even arrives. An unwitting Ramon remains in the kitchen at Camilla's request whilst the latter departs to tend to a newly-arrived guest whom she presumes to be the Viceroy. To her surprise, it is Felipe, who has returned from an experience of imprisonment and subsequent enlightenment in India. Irritated by one of the children who form part of the troupe, the jealous Ramon decides to find Camilla and proceeds towards a room containing a table. In front of him lie two doors. The door on the left leads to the balcony whilst the door on the right, as Ramon learns upon opening it, leads to another room which presents him with yet another door in the distance. As Ramon strides through these doors, Felipe enters through the room containing the table by means of the balcony which connects it to the foyer. Meanwhile, the door most recently opened by Ramon reveals yet another door in the distance. Yet again, the bullfighter opens the door, only to find Don Antonio, grand master of the troupe's performances, conducting a musical rehearsal.

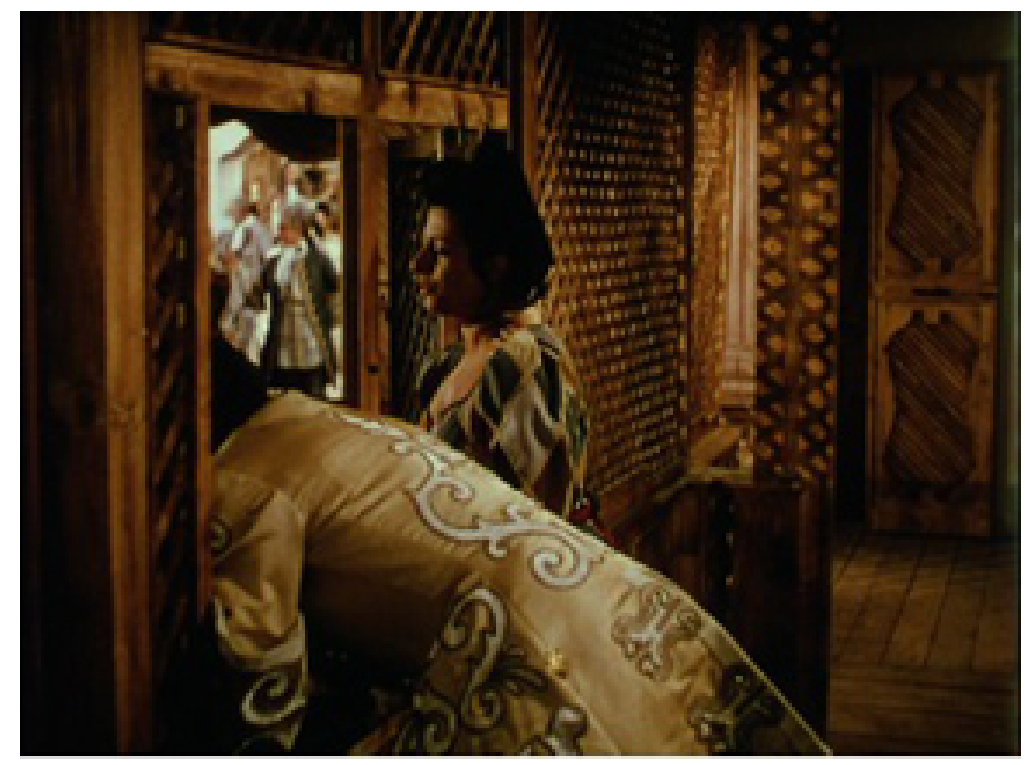

Figure 6: Figure G: Staging in Depth: Camilla speaks to the Viceroy as the other members of the court dance in the ballroom.

This entire sequence is filmed in one long take from the viewpoint of the door that connects the kitchen and the room containing the table. Ramon's progression towards the foyer through multiple doors also initiates a repeated extension of depth so we may simultaneously witness the physical trajectories of both characters (cf. Figs H - K). Thanks to the correspondences established by this objective use of depth, this coherent shot 

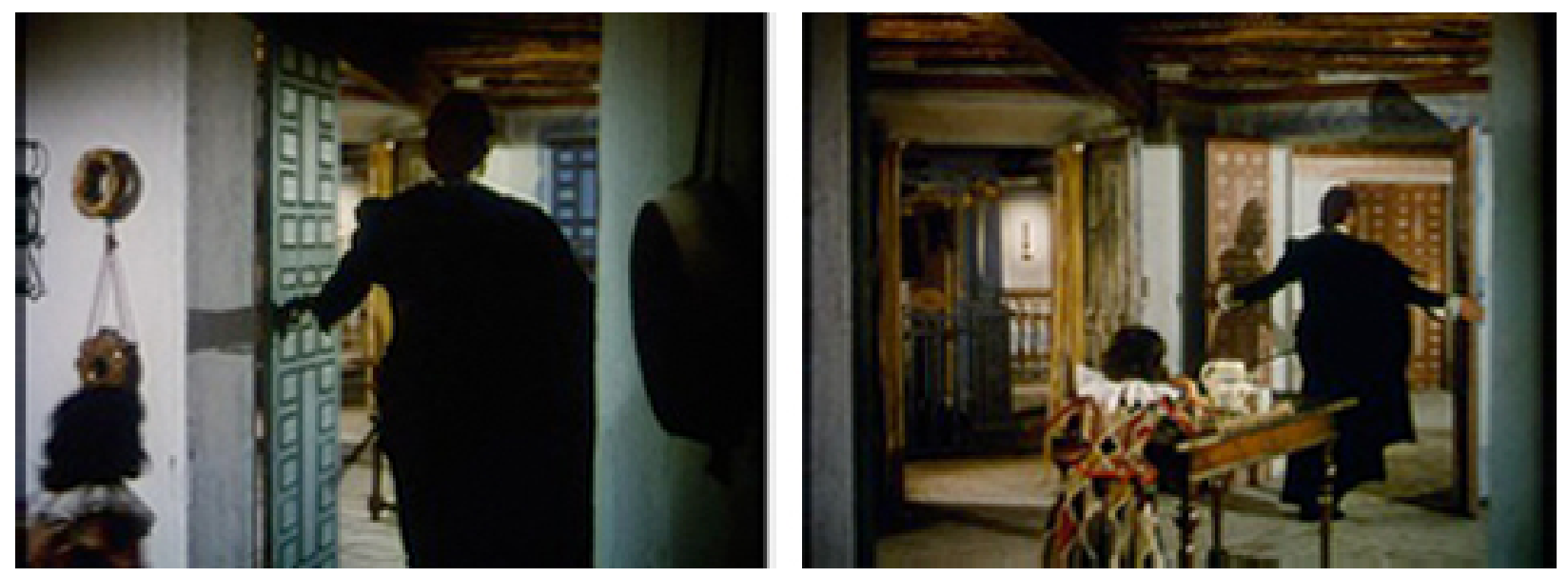

Figure 7: Figures H. - I: Repeated extension of depth of field: Ramon pursues Camilla.

poses as few interpretive problems as our first example: the mobility of the characters within different, deep spaces of the residence testifies to the labyrinthine nature of both the house and Camilla's love-life whilst also conveying the immediate motivations of the individual characters.
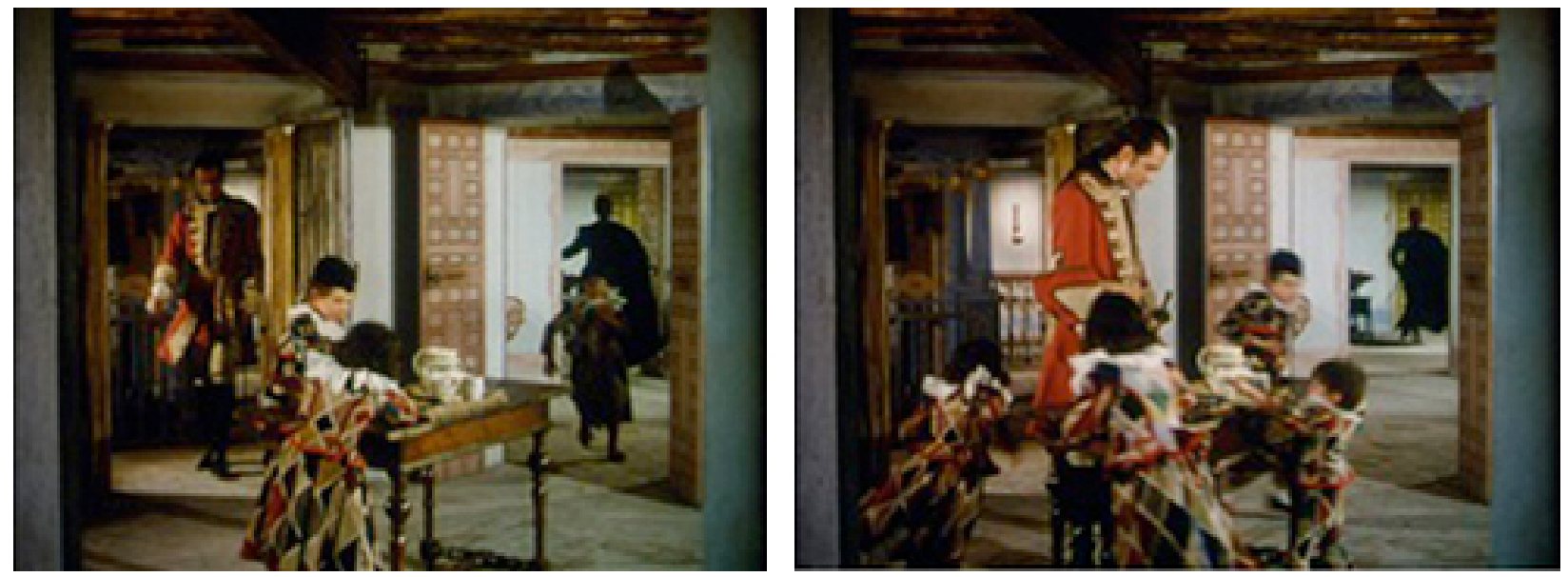

Figure 8: Figures J - K: Repeated extension of depth of field: Ramon pursues Camilla.

Yet within this film which here exploits depth so rarely and pragmatically, there is another scene which threatens to dispel a number of widely-accepted implications of composition in depth. Bridging our second and third examples is a series of medium shots conveying the exchange between Ramon and the unimpressed Don Antonio who, angry at Ramon's interruption, briskly shuts the door to his rehearsal room. At this point, the beaten Ramon turns around (as does the camera) and finally notices Felipe who is now playing with a number of the children from the troupe (cf. Fig. L). The bullfighter hurries to the balcony in an effort to corner Felipe only to return to the foyer, unlike Felipe who has, we realise, circulated differently within the maze-like network of rooms and doors (cf. Fig. M). The two men now face each other in the foyer, while the Viceroy's consort cowers between them.

Following a medium shot of each of the two suitors, Renoir returns to the carefully-framed image of the two men facing each other (cf. Fig. N). This third example of composition in depth poses a greater challenge: Ramon's path from the kitchen to the foyer remains in focus through the door located behind Felipe, as does the exterior space visible through the door located behind Ramon. The spectator may not necessarily expect Renoir to dispose of this deep space given his propensity for composing images in depth. However, the director unexpectedly flattens the figures of the two duellers and the Viceroy's consort against 

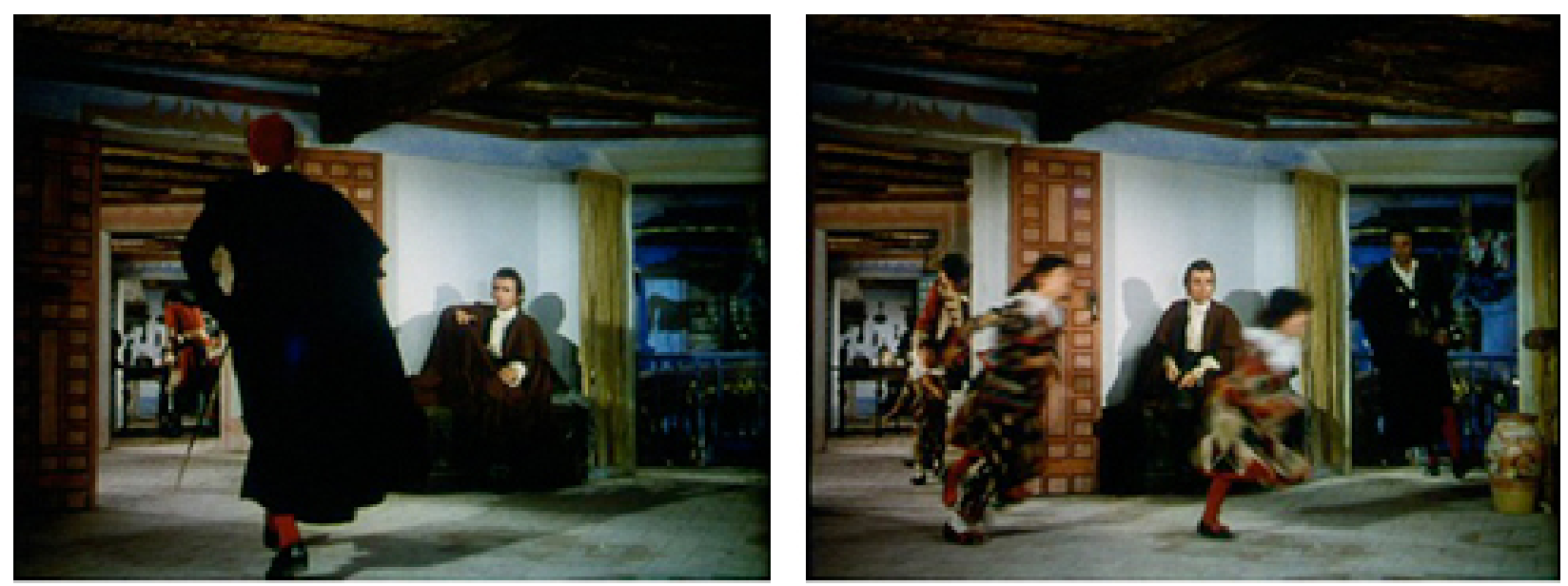

Figure 9: Figures L - M: Relations between figures are spread through out deep space: Ramon pursues Felipe, who is playing with the children in the room Ramon occupied in figures. H-K. Each disappears behind the foreground and emerge in different locations.

the symmetrically organised foreground. As a result, the sharply visible space is not gently incorporated into the image. Instead, it harshly contrasts with the formal, stage-like arrangement of the duellers which threatens to utterly nullify the relevance of this deep space to the drama.

In an interview granted after the production of the film, Renoir stated that by the time he had decided to adapt Merimée's play, he had concluded that the best way to transpose the subject to the screen was to subjugate his style to that of theatre. ${ }^{(6)}$ However, the elements presented as a dual set within this shot appear crassly uncomplementary and risk detracting from each other. In contrast with the carefully-plotted correspondences between actions unfolding in multiple planes of images in works as varied as Les Bas-fonds (1936) and The River, the uncharacteristically simplistic limpidity of the actions unwinding in the foreground is visually hampered by Renoir's decision to include such a transparently excursive element in this image. The significance of this shift in style is all the more remarkable since Renoir had stated in 1938 that:

[...] The more I work, the more I am lead to compose the image in depth in relation to the screen. The better it works, the more I avoid confrontations between two characters soberly placed beside in front of the camera as though in a photograph. ${ }^{(7)}$

Although this statement was made fifteen years before the release of The Golden Coach, a number of the most symbolically potent moments in The River, Renoir's latest film, were heavily reliant on deep staging (cf. Fig. O). Thus the mise-en-scène of this image risks confounding the spectator through the seemingly self-indulgent deviation from the standard applications of a technique by the very director who was once its foremost pioneer.

The careful construction of the plastic elements of the screen and the technological factors underlying the camera-work suggest that rather than being absolved of importance, the two deep fields remain relevant. Renoir, who was highly sceptical of the unmotivated use of technology in the cinema and in the modern age in general, required extremely strong lighting for Technicolor cinematography alone. ${ }^{(8)}$ Photography of deep fields posed additional problems because of the small lens aperture required for clear registration of multiple planes within deep space. Thus it was necessary to flood sets with additional artificial light. In this shot from The Golden Coach, the space leading from the foyer to the kitchen was clearly flooded with light and the space beyond the balcony was undoubtedly filled with blue-filtered light to convey the night-time setting. The strength of this lighting is made visible by the shadows of the characters occupying the foreground, particularly the consort whose shadow is projected each side of his head onto the wall behind him.

Furthermore, the use of a rack focus during Felipe's departure from the stage before Camilla receives the Viceroy's gift of a gold necklace indicates that Renoir did not employ the deep focus technology available 


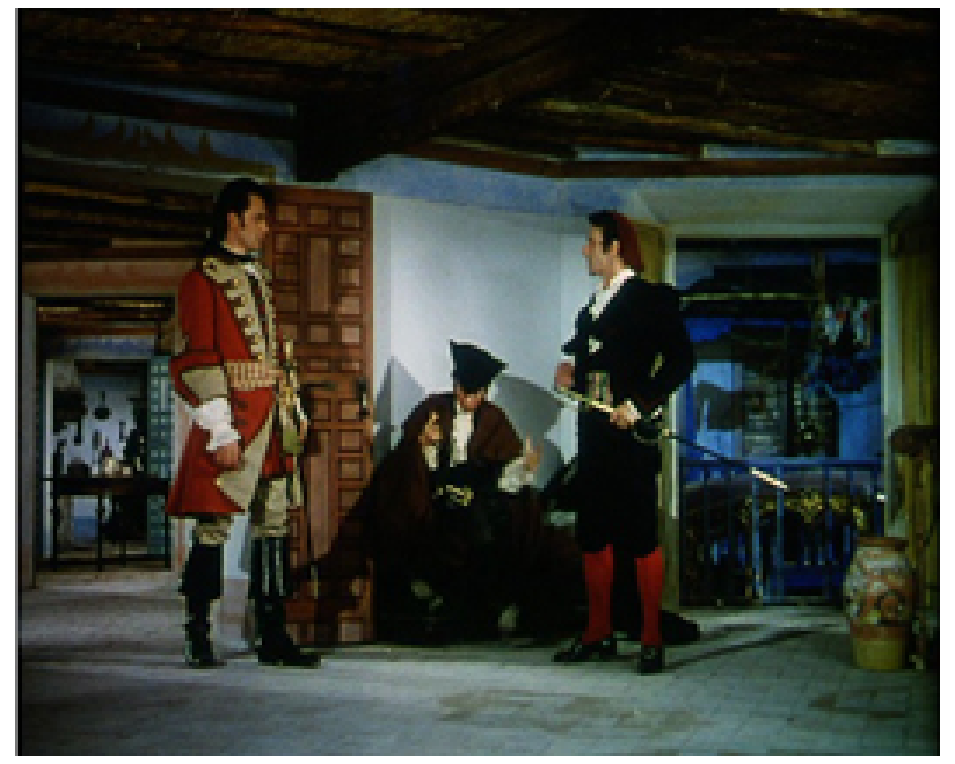

Figure 10: Figure N: Depth as (d)evolution? Felipe and Ramon prepare to duel.

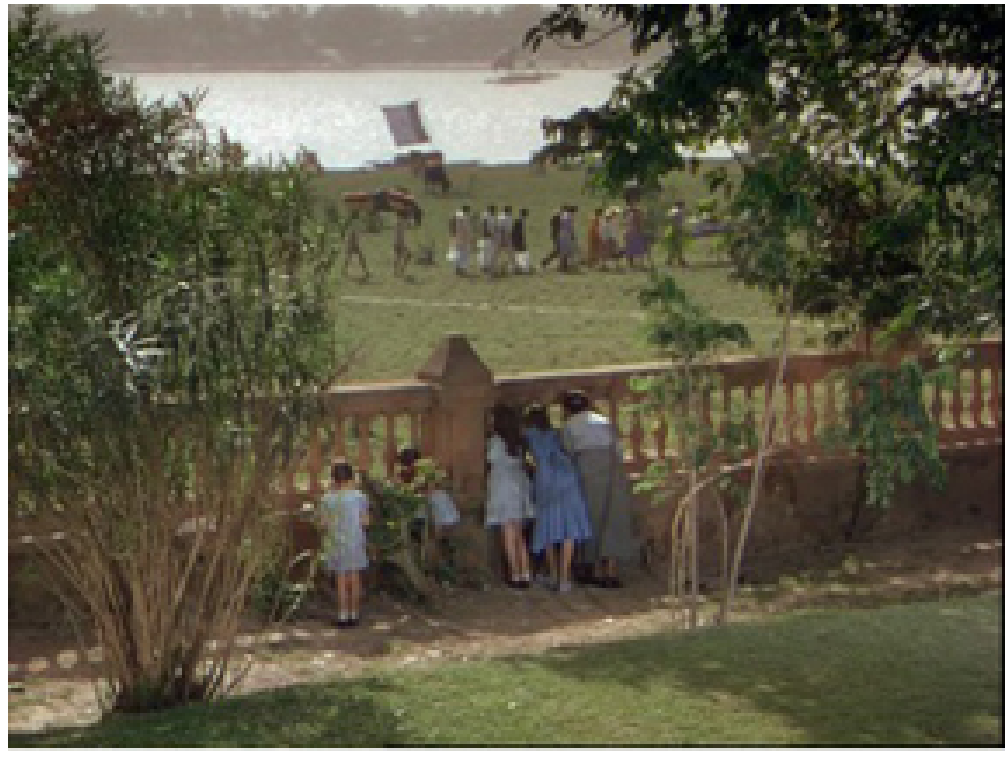

Figure 11: Figure O: Staging multiple events in depth in The River (1951): even when faced with the loss of their son, the English family must accept their loss for what it is and continue with their lives, simply because life goes on. This sentiment is echoed in the farthest planes of the image where a boat sails down the river outside the family home, its steerer removed from the world of the grieving family and symbolising the ceaseless march of time. 


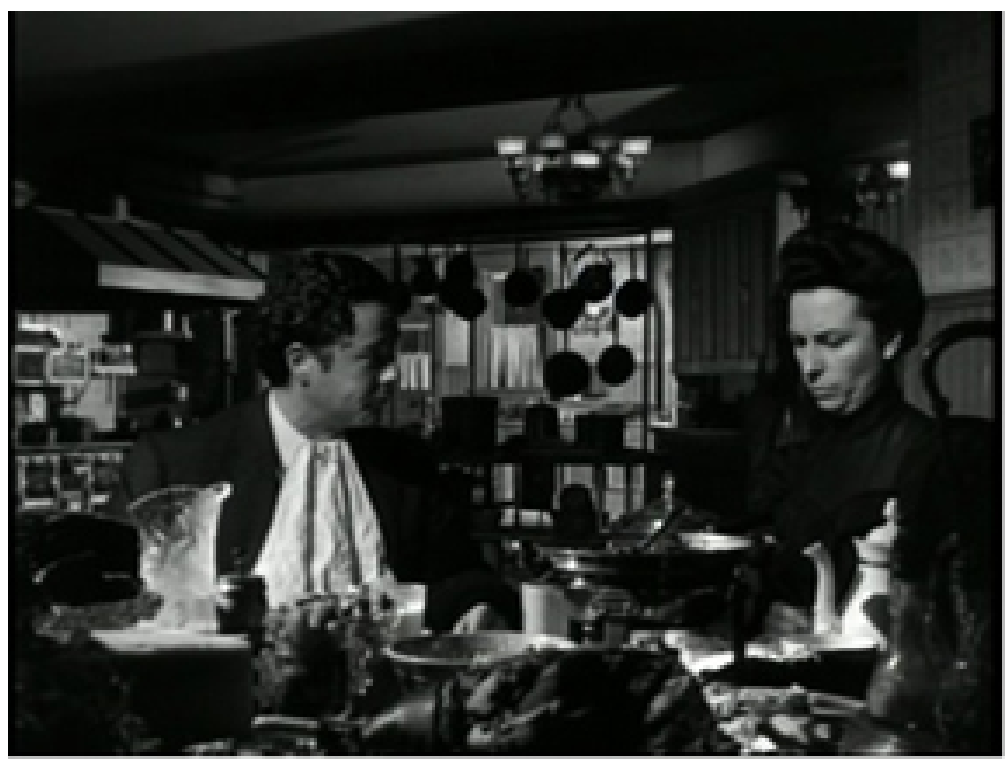

Figure 12: Figures P - Q: Two films made during the period between the production of La Règle du Jeu and The Golden Coach demonstrate the use of profondeur de champ to create coherence between different characters and their surroundings: Orson Welles' The Magnificent Ambersons (1942) and William Wyler's The Best Years of Our Lives (1946). In the first, the hanging pots and pans emphasise Fanny's containment within the domestic duties towards her selfish nephew, George. Note that her black clothes cause her to blend in with her surroundings. In contrast, George's white collar and serviette establish him as a more independent being within the confines of the kitchen and also as the person who benefits from Fanny's spinsterhood. In the second example, deep focus cinematography creates numerous interpersonal relations: $\mathrm{Al}$ (Fredric March) has forbidden Fred (Dana Andrews) to marry his daughter Peggy. In this shot, Al pretends to merely listen to the piano whilst watching Fred (Dana Andrews) in the phone-booth telephone Peggy to inform her that he is not at liberty to marry her. 
at the time, preferring instead to stage in depth despite the popularisation of the former by the 1950s in a movement catalysed by the innovative cinematography in the works of American directors, particularly Orson Welles (The Magnificent Ambersons, 1942 [cf. Fig. P) and William Wyler (The Best Years of Our Lives, 1946 [cf. Fig. Q]). ${ }^{(9)}$ This decision may be partly a result of Renoir's competence in deep staging which had become increasingly refined during the 1930s. It may also be attributable to the extra lighting which would have been necessary in order for the camera to register the most distant planes of the image had he opted for the small lens aperture required for crisp, deep focus cinematography. In any case, staging in depth remained a more primitive and, consequently, a more demanding means of rendering multiple planes in sharp focus. Thus we can assume that the visibility of deep space through the carefully aligned doors is deliberate.

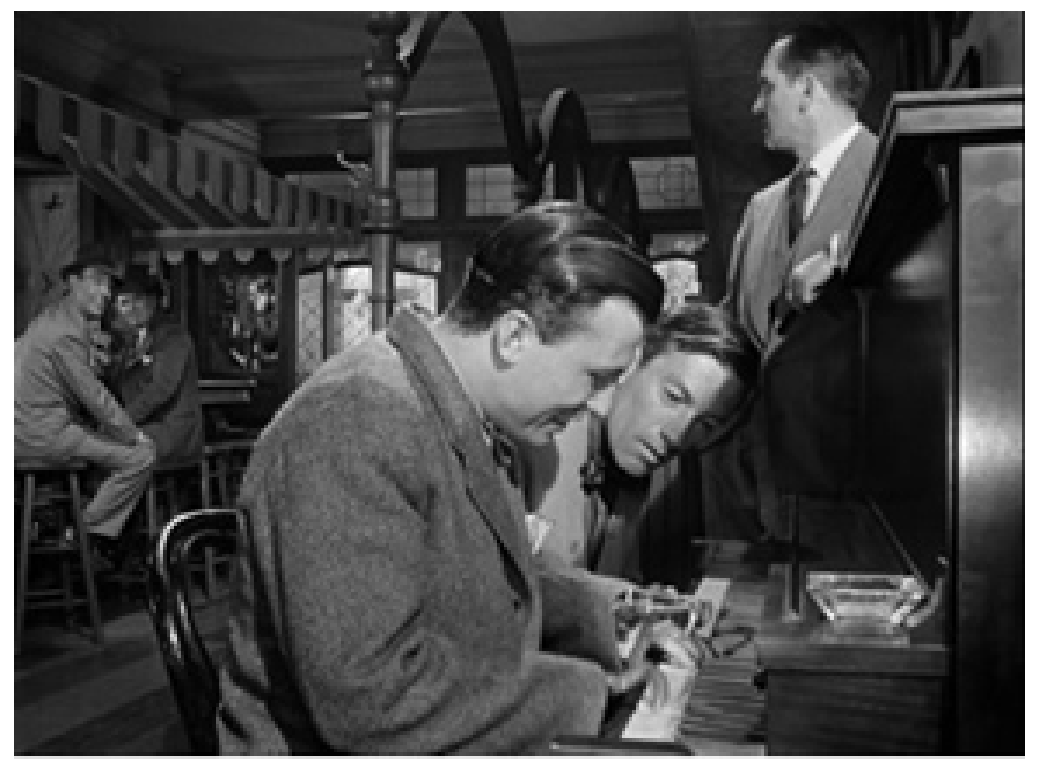

Figure 13: Figure Q.

In attempting to reconcile these two seemingly incompatible aesthetic derivatives, it is rewarding to notice that several aspects of this scene's strategic organisation of space are reminiscent of a strikingly similar shot from a film which exploited depth as a crucial agent in cinematographic language: in one of the most impressively composed images in La Règle du jeu, Lisette listens to a conversation between André Jurieux and Robert de la Cheyniest (cf. Fig. R). Both of the men occupy the foreground whilst Lisette's physical presence interrupts the deep, open space contained by the corridor leading to the foyer. Even farther in the distance, we can perceive Octave as he prepares to elope with Christine. The complexities of the crossed interpersonal relations and mixed emotions made manifest by the depth of the image are made possible through the same technique, later employed in this scene from The Golden Coach. However, adherence to the intricate coordination of plastic elements in this exemplar of 1930s realism is frustratingly abandoned: Felipe and Ramon assume a far more overtly formal stance than André Jurieux and Robert de la Cheyniest do in this shot from La Règle du jeu. This effort to flatten the characters against the symmetrically organised foreground results in a curiously staggered depth of space. The sense of the theatrical is further bolstered by the low ceiling which constricts the space and shifts our attention to the two characters.

As for the characters' surroundings, although a large mirror adorns the wall in this shot from La Règle du jeu and extends the spatial depth of the image, Renoir makes no attempt to deepen the space seen through the window beyond the similarly-located door behind Ramon: although the balcony door grants spectators a view of a window in another section of the house, the window's shutters are closed and do not privilege us with a view of the distant room. Conversely, La Chienne (1931), Boudu sauvé des eaux (1932) and Partie de Campagne (1936) are but three examples of films in which Renoir explores the motif of the window as a connector of interior and exterior spaces. The apparent irrelevance of the deep space in front of the window is even more blatant when compared to previously-discussed scene outside the Viceroy's ballroom where a 
large number of people dancing in the distance are constructively integrated into the personal and social signification of the image.

Furthermore, we are not encouraged by the repeated extension of depth encountered in our second example or by the camera to suspect what lurks beyond the parameters of the rigid frame. Unlike the inquisitive lens that roams, inquires into and dodges action as an "invisible guest, curiously perceiving but without any privilege apart from its invisibility"(10) in La Règle du jeu, the static camera in The Golden Coach lulls us into a false sense of security. Consequently we are tempted to neglect the space in front of the closed window and may forget to remain vigilant until our attention is diverted towards an item we may not otherwise notice. However, if we draw our attention away from the shutters that restrict our view of the interiors of the opposite section of the house, we shall discover the not unimportant emblem of wealth, success and (if we believe the Viceroy) a nation: partly concealed by the balcony's balustrade but unmistakably present, the golden coach is there for those who decide to notice it.

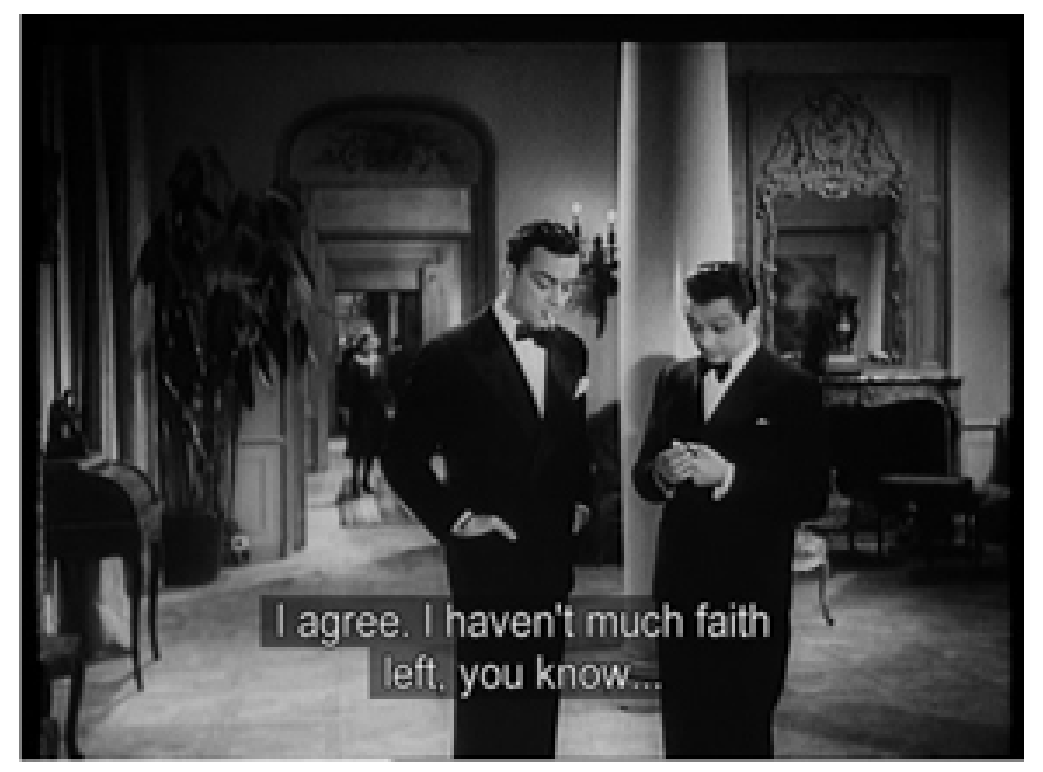

Figure 14: Figure R: Relations in depth: Lisette observes Jurieux and Robert ironically discussing friendship while Octave prepares to elope with Christine.

It should be noted that the elusiveness of the coach's presence in this shot is not exceptional within the context of the film: the restricted view of the coach represents a development of a motif established earlier in the film story, reprised before the duel and recapitulated after Felipe and Ramon are reprimanded. In two shots from the scene of pursuit within Camilla's residence, the weary actress looms on the balcony overlooking her coach. In a similar fashion, the balusters largely block the coach from the spectator's view (cf. Figs. S - T). Even at the very beginning of the film, when the members of the court rush to the windows to observe the arrival of the Viceroy's new symbol of the state, they are not privileged with the same view of the coach as the viewers of the film.

All of the palace windows made visible to the spectator are composed of a criss-cross design which inhibits their view of the coach (cf. Figs. U - V). These three occasions establish the coach as a concrete realisation of unattainable desire rather than a material object ripe for possession. It is this motif of elusive desire which is reprised during the duel.

This aspect of the golden coach is bolstered by its spatial location: it is parked in the courtyard of Camilla's residence. The courtyard features as a locus of desire in two of Renoir's earlier films made during the rise of the Front Populaire, Le Crime de Monsieur Lange (1935) and Les Bas-fonds (1936). In the former it features as an area of redemption that links all of the exploited employees together as they establish a brighter future for the production of the Arizona Jim franchise through the "collective" murder of Batala. In the latter, the 


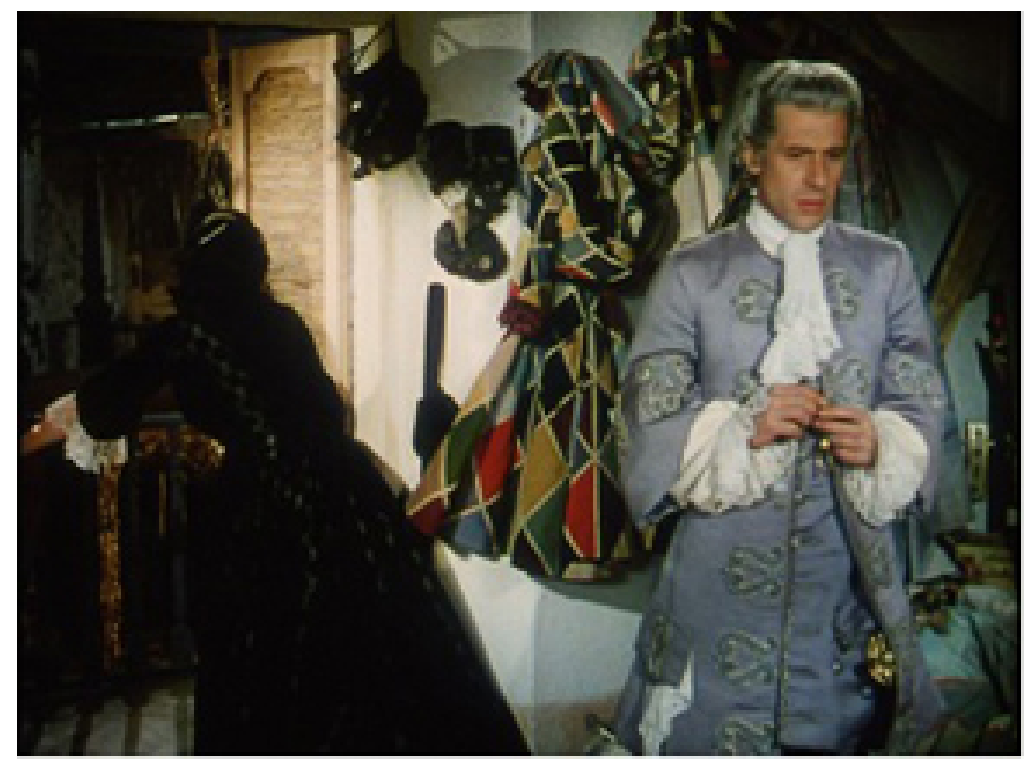

Figure 15: Figures $\mathrm{S}-\mathrm{T}$ : Cet objet obscur du désir: note the balusters indicating the intangibility of the coach. See La Règle du Jeu (next page) for a precursor to this mode of spatial organisation: the frame of left door designates the room to which Christine and Saint-Aubin are fleeing as a forbidden space.

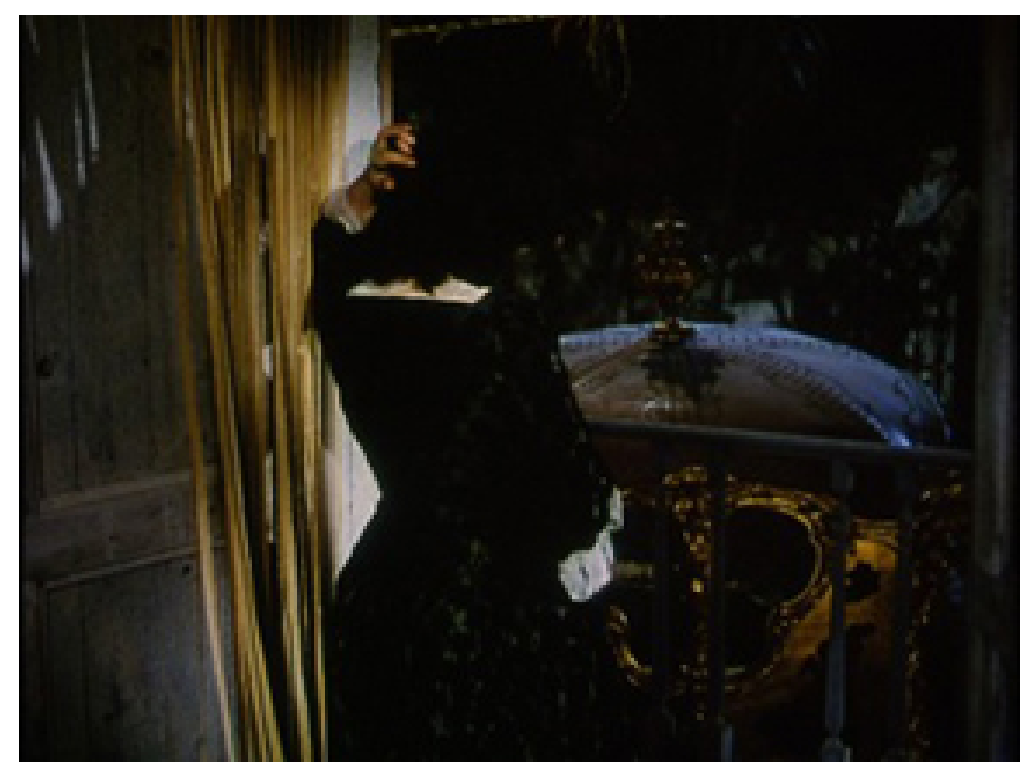

Figure 16: Figure T. 


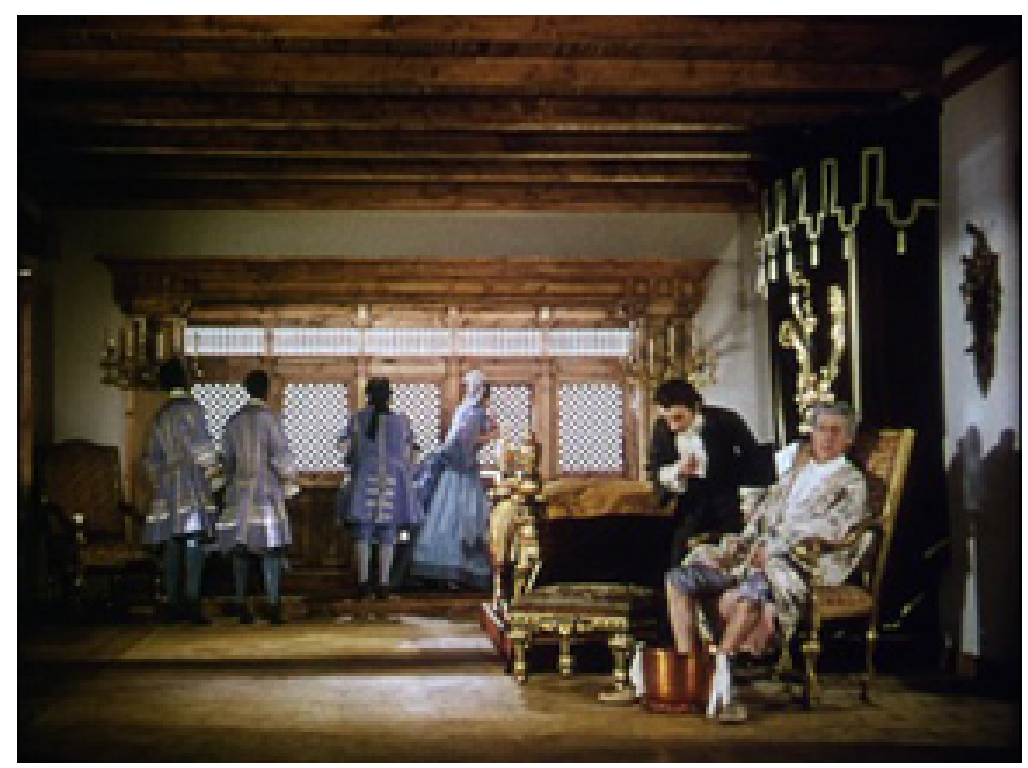

Figure 17: Figures U. - V: Two further examples of the restrictive view of the coach granted to eager onlookers.

homeless characters share their stories and hopes with each other, dreaming of escape from the misery of the shelter.

In the same film, deep staging establishes the courtyard as the pathway to escape from the misery of the shelter (cf. Fig. W). Moreover, the courtyard later serves once more as the locus of the murder of an oppressive figure of authority, in this case their miserly landlord Kostylev. In The Golden Coach, the courtyard again becomes a locus of desire, this time through the presence of the coach: the camera's view of the coach through the open door behind Ramon firmly establishes the coach as a fugitive object of desire, as unattainable as the mercurial Camilla. The balusters restrict our view of the coach, suggesting that it is not only beyond the hold of its current owner but of all concerned, whether they desire it (Camilla and the nobility) or not (Felipe and Ramon).

This unconventional use of deep space also performs a microcosmic function: although the camera does not move, the structure of the image complements the overall architecture of Camilla's residence, reminding us that we must remember to look around corners and consider that the camera is hiding objects of relevance: three different doors lead from the foyer of her residence to the various other rooms. Within each of the three rooms located behind these doors, additional doors may be opened, as in the case of the room located behind Felipe which leads into the kitchen visible in this shot. Furthermore, the balcony which is accessible from within the house stretches along the exterior of the house overlooking the courtyard. Thus the balcony connects rooms that are multiple rooms and doors apart so that even the characters navigating intently throughout the space lose track of each other. (In fact, this is exactly what happens during the second previously-described long take during which Ramon attempts to corner Felipe.)

Initially, the open door behind Felipe seems even more diegetically and aesthetically excursive than the glimpse of the closed shutters: the doorway reveals a deep space incorporating not one but two distinct planes of space in addition to the foreground. The first of these is visibly occupied by a table. The second, farthest plane is evidently a kitchen, the doors of which are also open. The props obstructing Ramon's progression through the house permit us to perceive three distinct planes of space. However, the relation between this deep space and the characters occupying the foreground is difficult to elucidate since the objects are so intricately aligned that their presence seems necessary solely in order to establish the depth of the space. Thus the relevance of the former to the affairs of the latter is not as strikingly clear as during the scene on the Viceroy's balcony or the shot conveying the two suitors' respective searches for Camilla. Furthermore, the difficulties posed by the closed window beyond the door behind Ramon derive from issues incurred 


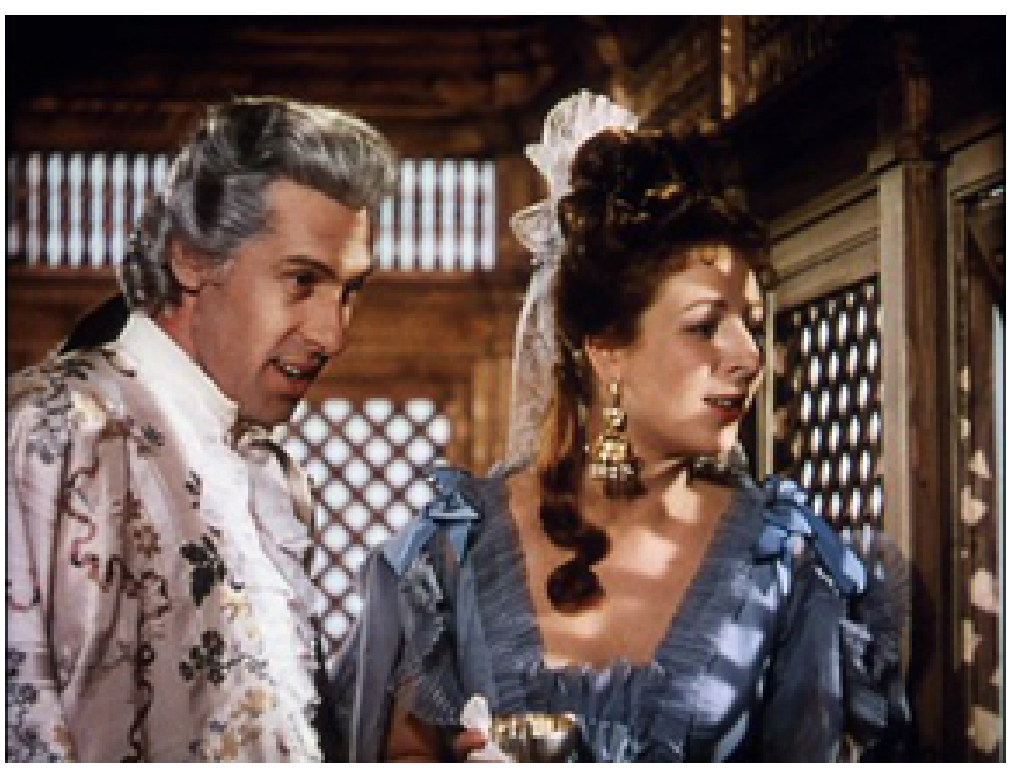

Figure 18: Figure V.

through inattentive observation rather than fundamental incompatibility of styles. Visual navigation of the space behind Felipe seems futile.

In order to determine the implications (if any) of this atypical employment of depth, I suggest we turn to André Bazin whose theories of time and space in the cinema advocated a strictly realist aesthetic. ${ }^{(11)}$ In his effort to locate the staging of multiple events in depth and, by extension, Renoir's work of the thirties within the teleological evolution of cinematographic realism (which also included films by directors such as Robert Flaherty, F. W. Murnau, Welles and Wyler), Bazin praised profondeur de champ, wide-angle shots and long takes for their ability to create a sense of continuity in both time and space. Renoir's uncharacteristic and apparently unmotivated use of deep staging in The Golden Coach challenges Bazin's argument that composition in depth represents a revolution in mise-en-scène and découpage. In his seminal theory and criticism, Bazin established the aforementioned attributes of "realistic" cinematography, beginning with a critique of the formal structure of the image:

Profondeur de champ places the spectator in a relation with the image which is closer to that which he [/she] shares with reality. [...] Independent of the very content of the image, its structure is more realistic. ${ }^{(12)}$

Although I wish to interrogate our conception of realism, a discussion of "what is reality?" is beyond the scope of this essay. Still, we can conclude that the revelation of different planes of the image conforms to Bazin's conception of the realist aesthetic: Bazin claims that the flou (or "blurring") is principally linked with the close-up and montage, and that it otherwise remains a contradiction representing some inexplicable part of space. ${ }^{(13)}$ Consequently, a clear background may be viewed as signifier of reality. However, as already noted, the depth of the largely-vacant space in this scene from The Golden Coach instead emphasises the theatricality of the picaresque duel and consequently undercuts any aura of likeness with what we conveniently label "reality".

Bazin notes that this visual clarification permits the spectator to form correspondences between different objects and/or characters within different planes of the image, stating that it transforms what would otherwise remain a homogeneous space into a cinematographic image imbued with logical and dramatic relations. ${ }^{(14)}$ Since the farther planes of the image are not modified by a flou, Bazin necessarily implies that a relationship is established between the space contained by the corridor and the characters occupying the foreground. This supposedly overrides my previous suggestion that the table, pots and pans serve the purely formal function of emphasising the depth of the space. Furthermore, if we subscribe to his theory we must consequently accept 
the realist aesthetic allegedly inherent to the staging of this scene, regardless of the deliberately spectacular flair created by the colour design which constantly reminds us of the theatricality of the characters' actions and affairs. Bazin stresses the role of the spectator in the interpretation of composition in depth, stating that:

As a result, [composition in depth] implies a more active mental attitude and even a positive contribution from the spectator to the mise-en-scène. [...] The possibility for the image to have sense partly depends on his/her attention and his will. ${ }^{(15)}$

This essential ambiguity is characterised by the selective nature of the viewing process permitted by composition in depth as opposed to the coercive viewing experience provoked by montage. ${ }^{(16)}$ From Bazin's theorisation of the viewing experience, we can conclude that the spectator cannot simply dismiss the complications presented by this problematic spatial void: we must form a relative association between the visibly isolated realistic and theatrical elements that form this harsh contrast of aesthetics. Thus we are forced to completely reconsider the relation that exists between the duelling characters and the very world they inhabit.

Rather than condemning Renoir for aesthetic treason, I propose that we adhere to Bazin's claim that profondeur de champ represents a revolution in mise-en-scène in both the context of Renoir's oeuvre and in the aesthetic of cinematographic realism. Consideration of the aspects of Bazin's proposals outlined above demand that we accept the possibility of development of the role of depth of field beyond the literary confines of his theory. If one considers Bazin's declaration that the possibility for the "realistic" image to have sense partly depends upon the spectator's will and the selectivity of relations within deep shots, we can conclude that the crucial ambiguity within any supposedly realistic film lies in the spectator's or director's definition of realism. Moreover, the definition thereof is directly contingent on the context of the film: in the case of Lewis Milestone's All Quiet on the Western Front (1930), it is the impact of the sound of machine-guns firing and the physical grime of the trenches that encourages remarks on the film's realism. In the case of Orson Welles (much like that of Renoir's 1930s masterworks), "realism" denotes the photography of a frame carefully composed in depth which allows the spectator to perceive multiple visual elements and the relations between them. ${ }^{(17)}$

As for later films such as John Cassavetes' Shadows (1959), it is chiefly characterised by use of a hand-held camera, by deceptively casual framing and the impression of improvisation on the part of the actors. The case of Renoir is particularly complex as there is a progressively decreased reliance on what he called le réalisme extérieur (or la vérité extérieure) as a means of exposing the réalisme intérieur (or la vérité intérieure) of his characters. In his autobiography, Renoir refers to one of his great American masters in an effort to illustrate his realist aesthetic:

An actor is to play the role of a fisherman. Concerned with realism, he refuses any make-up whatsoever. He goes to live in a little Breton port and even takes part in fishing expeditions at sea. He wears the worn clothes of a real fisherman. His complexion is truly tanned by the salty ocean winds. When we pass by him on the road, we cannot distinguish our actor from the hard-boiled fishermen. After this minute preparation, he plays his role. Certain scenes may be filmed in Brittany on a real boat. The director may not even hire a double for the actor during a scene involving a real storm. The result shall be that our actor, if he is not a genius, will look like a complete ham. It would even seem that the natural elements surrounding this artificial being could only reveal his falseness all the more. Let us suppose now that Charlie Chaplin is playing the role of the sailor. The recording takes place in a studio in front of a painted backdrop. Chaplin shall not even bother to wear a real sailor's clothes. We see him dressed in his usual jacket, topped off with his bowler hat, wearing his huge shoes and playing with his cane. After a few minutes on the screen, we would submit to the fantasy of the costume and would be convinced that we had a true sailor before our eyes...(18)

As one may gather from the above explanation, "cette question de la vérité extérieure ou intérieure"(19) was of primordial importance not only to the costumes of the character but to the décor of the setting. Bazin fails to consider the viability of his theories of realism in relation to Renoir's aesthetic of réalisme intérieur: in fact, The Golden Coach is the only instalment of Renoir's trilogy of spectacle completely elided by Bazin in 
his otherwise comprehensive Jean Renoir. ${ }^{(20)}$ Even in a retrospective conference speech on the development of French cinema from the 1930s to the present (then 1957), Bazin saw no merit in including The Golden Coach in the same line of praise reserved for French Cancan (1954) and Elena et les hommes (1956). (21) One may speculate whether Bazin was utterly confounded by Renoir's apparent travesty of realism (especially in the aftermath of The River on which he lavished unbridled praise), ${ }^{(22)}$ and saw the concurrence of styles as an irreconcilable clash, far more successfully tamed in the latter films.

In this situation, it is imperative that we turn our attention away from the individual, concrete objects within the space despite Bazin's insistence on their relevance within deep spaces. ${ }^{(23)}$ We should look rather to the actual depth of the space contained beyond the doorway, which permits the spectator to establish not one but two relations which each refer us to Renoir's concept of le réalisme intérieur. The first of these pertains to the characters' inner preoccupations, the second to their sense of spatial location. Each derives from the very impression of distance created between the duellers occupying the foreground and the depth of the space visible through the door.

First of all, in combination with the deliberately stage-like foreground, the vertiginous pull of the space against the rigidly lateral arrangement of the foreground emphasises the extent to which the two suitors are governed by their preoccupation with certain immediate concerns at the expense of other equally-pressing matters: both characters have come in search of Camilla but fight each other, completely neglecting to locate her within the house. Although it is Ramon who initiates the duel, neither of the characters reflect on the presence of the consort which clearly indicates the presence of the Viceroy who also poses a threat to their courtships. To this extent, they are as fallible as Camilla: she proceeds from one lover to another within the house, each time believing that she has found true love only to have her confident beau replaced by another who evokes the same sentiment within her. Thus the spatial organisation of this shot exemplifies the characters' immersion in their own, watertight world of personal, pressing concerns.

The emphatic fixity of the characters also illustrates the relation between themselves and Camilla's residence. Although a more conventionally constructive use of deep space (such as the type used in our second example from the film or in the previously-discussed scene from La Règle du jeu) could have crystallised the close relation between the duellers and the residence, Renoir vies to obtain the opposite effect: the visible length of the space is relegated to the background and remains unbroken by characters.

This specific employment of depth illustrates the extent to which the characters are connected to this specific section of the house at the expense of any relationship with the myriad of rooms surrounding them. Renoir achieves this effect by accentuating the closeness of their space rather than opening the space to other areas and worlds. The parameters of this space are breached only by the frenzied physical sparring of the swordfight which, as it escalates out of control, further testifies to the extent to which the characters are immersed in their own affairs above all else. In light of the characters' actions and visible sentiments, we may determine that the dual relationship formed by this particular staging of elements in depth demonstrates a successful attempt to convey the réalisme intérieur of the characters without relying on le réalisme extérieur: this is achieved through the refusal to distribute on-screen elements in a manner which would appeal to the passive spectator and the exploitation of both the overtly theatrical arrangement of décor and the visible depth of the space leading to the kitchen.

Renoir himself was evidently conscious of his aesthetic audaciousness. At a conference held one year after the release of The Golden Coach, the director declared that:

Personally, I have made many films belonging to the genre of le réalisme extérieure. I have humbly tried - perhaps without actually succeeding at times - to add le réalisme intérieure. I must say that deep down that for me, this réalisme extérieure has always been a means of arriving at le réalisme intérieure ${ }^{(24)}$.

Just as improvements in panchromatic emulsions gradually allowed for a visually deeper cinematographic composition, The Golden Coach demonstrates an evolution towards representing le réalisme intérieur without resorting to le réalisme extérieur. Although Bazin did not write about realism in relation to Renoir's concept of le réalisme intérieur, this shot demonstrates how The Golden Coach pushes at the edges of Bazin's conception of realist cinematography without ever utterly defying it. While the colourful façade of the 
residence remains as inherently theatrical and larger-than-life as Camilla, the vertiginous sensation evoked by the space beyond the door draws us into the characters temporary mental isolation from their original concern for Camilla and conveys their physical alienation within Camilla's residence. Furthermore, Renoir's deviance from previously-established motifs such as open windows beckons us to explore the existence and significance of objects within the parameters of the frame. A new approach to Bazin's theories of cinematographic realism guide us through one of Renoir's most flagrantly visually indulgent set-pieces, revealing innovative exploitation of depth at a time when people were convinced that the Renoir of the 1930s was dead: ${ }^{(25)}$ Active participation in the image as advocated by Bazin reveals that the realism of Renoir's pre-war work had not dissipated - it had simply evolved. Films like La Règle du jeu continue to surprise us because they are so deceptively understated. The Golden Coach surprises us only if we are willing to scrape below the glaring artifice of Technicolor and exhume its réalisme intérieure.

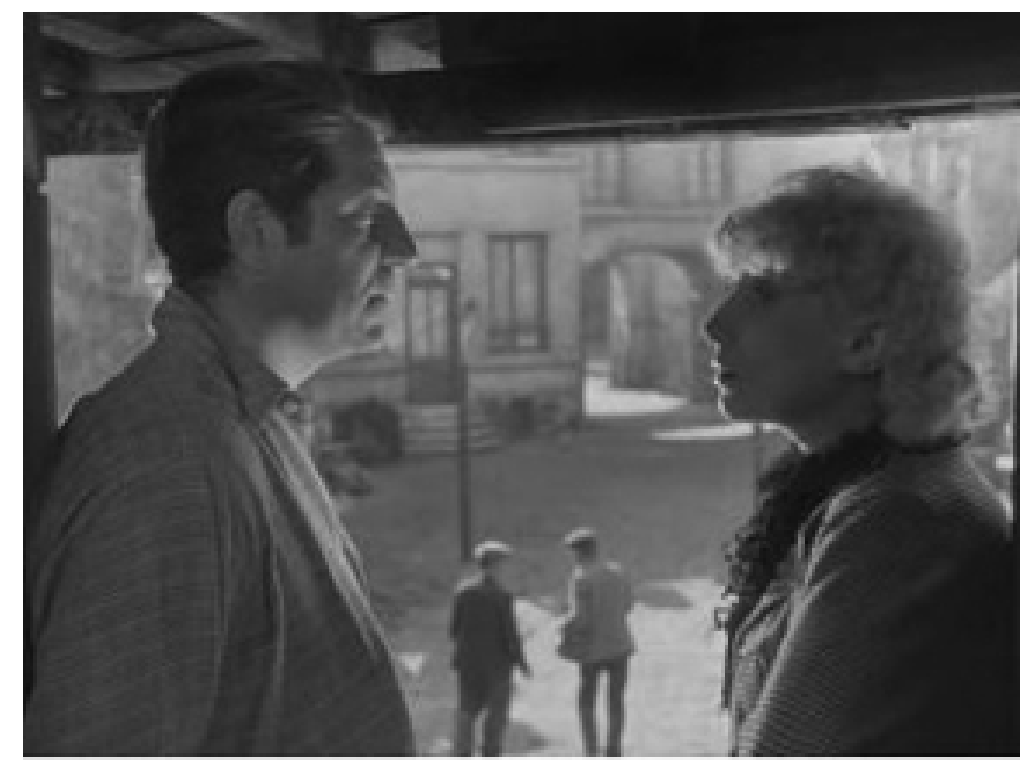

Figure 19: Figure W. From Les bas-fonds: Pepel and Vassilissa dream of escape but neither can trust the other's motives.

\section{Notes}

1. Jean Renoir. Ma vie et mes films. $2^{\text {nd }}$ ed. Paris: Flammarion, 2005. 247. Print. Note: all translations of French texts are my own unless otherwise indicated.

2. André Bazin. "Le réalisme cinématographique et l'école italienne de la Libération." 1948. Qu'est-ce que le cinéma? 18th ed. Paris: Editions du Cerf, 2008. 269.

3. For a compilation of some of Bazin's key texts on realism in the cinema, see Bazin, 2008. For a study of Renoir's film's informed by Bazin's advocation of the realist aesthetic, see: Jean Renoir. Ed. François Truffaut. Paris: Ivrea, 2005.

4. David Bordwell and Kristin Thompson. Film Art: An Introduction. 8th ed. Boston: McGraw-Hill, 2008. 172-173. Print. All styles are the authors' own. For further reading on the history of depth of field and deep space, see: David Bordwell. "Making the Image Intelligible." On the History of Film Style. Cambridge, MA: Harvard UP, 1997. 163-237.

5. Tom Paulus. "The View across the Courtyard: Bazin and the Evolution of Depth Style." Film International 5.6 (2007): 68.

6. Jean Renoir. Écrits: 1926-1971. Ed. Claude Gauteur. Paris: Ramsay, 2006. 59. For the full article, see 
$53-64$.

7. Ibid.

8. Renoir appears to have been fully aware of the new difficulties he would face when filming a more varied range of hues: along with his nephew Claude, who had previously worked as cinematographer to great acclaim on The River, Renoir hired a Technicolor technician, in this case Joan Bridges, for the very first time. Note that Bridges had worked on some of the most critically-acclaimed colour films of all time including four of Michael Powell and Emeric Pressburger's most ambitious films to date: A Matter of Life and Death (1946), Black Narcissus (1947), The Red Shoes (1948) and The Tales of Hoffmann (1951). For Renoir's opinion of technology and progress, see: Jean Renoir. "Ce bougre de monde nouveau." Cahiers du Cinéma 7.78 (1957): 4-10. Print; Jean Renoir. For the director's early reactions to Technicolor, see: Jean Renoir. "La couleur au cinéma." 1936. Le passé vivant. Ed. Gauteur, Claude. France: Editions de l'Étoile / Cahiers du Cinéma, 1989. 19-20.

9. For Bazin's analysis of Wyler's The Best Years of Our Lives which treats fig. Q, see: Andre Bazin. "William Wyler ou le janseniste de la mise-en-scène." 1948. La Revue du Cinema. Ed. Antoine de Baecque. Paris: Gallimard, 1992. 161-88.

10. André Bazin. Jean Renoir. Ed. François Truffaut. Paris: Ivrea, 2005. 80.

11. See footnote 3 for relevant texts. Two of Bazin's key texts inform this essay: 1) André Bazin. "L'évolution du langage cinématographique." Qu'est-ce que le cinema? 18th ed. Paris: Cerf-Corlet, 2008. 63-80. Print; 2) André Bazin. "Pour en finir avec la profondeur de champ." Cahiers du Cinéma. 1.1 (1951). $17-23$.

12. Bazin, 2008. 75 .

13. Bazin, 1951, 19-20.

14. Ibid., 22.

15. Bazin, 2008. 75.

16. Ibid., 76.

17. For Bazin's analysis of Wellesian realism, see: André Bazin. Orson Welles. 3rd ed. Paris: Cahiers du Cinéma, 2006.

18. Renoir, 2005. 144-45.

19. Ibid., 146.

20. See bibliography for publication details. Note that Bazin even devotes pages to Renoir's work in the theatre (Bazin, 2005. 114-122) but gives no reason for avoiding The Golden Coach.

21. André Bazin. Le cinéma français de la Libération à la Nouvelle Vague (1945-1958). Ed. Jean Narboni. 2nd ed. Paris: Cahiers du Cinéma, 1998. 36-37. Print. For a full transcript of the speech, see 23-41.

22. Bazin, 2005. 99-113.

23. Bazin, 1951. 22-3.

24. Renoir, 2006. 308. This article contains extracts from a conference held at the Institut des hautes études cinématographiques.

25. Critics such as Jacques Doniol-Valcroze embraced this new phase in Renoir's career. [cf. Jacques Doniol-Valcroze. "Camilla et le don." Cahiers du Cinéma 4.21 (1953): 44-6. Print.] However, his sentiments were not universal. For a particularly unflattering review of The Golden Coach, see: Herman G. Weinberg. "Lettre de New-York." Cahiers du Cinéma 4.24 (1953): 35-37. Print. For Weinberg, Renoir is preoccupied with saturating the visual impact of the film at the expense of the humanity and believability. He lambastes the film to such an extent that the Cahiers editors evidently felt obliged to add a preceding note, explaining that they themselves did not feel so harshly about Renoir's latest film. 


\section{References}

\section{Bibliography (Books and articles)}

Baecque, Antoine de, ed. La Revue du Cinéma. Paris: Gallimard, 1992.

Bazin, André. Le cinéma français de la Libération à la nouvelle vague (1945-1958). Ed. Jean Narboni. $2^{\text {nd }}$ ed. Paris: Cahiers du Cinéma, 1998.

. Jean Renoir. Ed. François Truffaut. Paris: Ivrea, 2005.

. Orson Welles. 3rd ed. Paris: Cahiers du Cinéma, 2006.

. "Pour en finir avec la profondeur de champ." Cahiers du Cinéma. 1.1 (1951) 19.

. Qu'est-ce que le cinéma? $18^{\text {th }}$ ed. Paris: Cerf-Corlet, 2008.

. "William Wyler ou le janséniste de la mise-en-scène." 1948. La Revue du Cinéma. Ed. Antoine de

Baecque. Paris: Gallimard, 1992. 161-88.

Bordwell, David. On the History of Film Style. Cambridge, MA: Harvard UP, 1997. 163-237.

Bordwell, David and Kristin Thompson. Film Art: An Introduction. $8^{\text {th }}$ ed. Boston: McGraw-Hill, 2008. 172-173.

Doniol-Valcroze, Jacques. "Camilla et le don." Cahiers du Cinéma 4.21 (1953): 44-6.

Narboni, Jean, Janine Bazin and Claude Gauteur, eds. Entretiens et propos. Paris: Cahiers du Cinéma, 2005. 78 .

Paulus, Tom. "The View across the Courtyard: Bazin and the Evolution of Depth Style." Film International 5.6 (2007): 62-8, 70-5.

Renoir, Jean. "Ce bougre de monde nouveau." Cahiers du Cinéma 7.78 (1957): 4-10.

. Le passé vivant. Ed. Gauteur, Claude. France: Éditions de l'Étoile / Cahiers du Cinéma, 1989. . Écrits: 1926-1971. Ed. Claude Gauteur. Paris: Ramsay, 2006.

. "Quelque chose m'est arrivé." Cahiers du Cinéma 2.8 (1952): 31-2.

Weinberg, Herman G. "Lettre de New-York." Cahiers du Cinéma 4.24 (1953): 35-37.

\section{Bibliography (Films)}

Cassavetes, John. Shadows. Lion International Films, 1958.

Milestone, Lewis. All Quiet on the Western Front. Universal Pictures, 1930.

Renoir, Jean. La Chienne. Braunberger-Richebé, 1931.

. Le Crime de Monsieur Lange. Obéron, 1935.

. Les Bas-fonds. Les Films Albatros, 1936. Criterion, 2004. DVD.

. La Grande Illusion. 1937. Réalisation d'Art Cinématographiques. . La Règle du jeu. Nouvelles Éditions Françaises, 1939. Criterion, 2004. DVD.

- The River. Oriental International Films, 1951.

. The Golden Coach. Panaria Films, 1953. Criterion, 2004. DVD.

. French Cancan. Gaumont, 1954.

. Elena et les hommes. Franco-London Films, 1956. 
Welles, Orson. Citizen Kane. RKO, 1941. Universal, 2003. DVD.

. The Magnificent Ambersons. RKO, 1942. Universal, 2006. DVD.

Wyler, William. The Best Years of Our Lives. Samuel Goldwyn Company, 1946. MGM, 2004. DVD.

\section{Author Information}

Barry NEVIN is in the second year of his PhD in French Studies at National University of Ireland, Galway. His research focuses on the relationship between the organisation of space and the depiction of class in the films of Jean Renoir. His other interests include poetic realism, 1930s melodrama, representations of French history in film and the use of colour in film. 